\title{
The Print Media Convergence: Overall Trends and the COVID-19 Pandemic Impact
}

\author{
Marina Sheresheva ${ }^{1, * D}$, Lyudmila Skakovskaya ${ }^{2}$, Elena Bryzgalova ${ }^{2}$, Anton Antonov-Ovseenko ${ }^{3}$ \\ and Helen Shitikova 4
}

Citation: Sheresheva, Marina, Lyudmila Skakovskaya, Elena Bryzgalova, Anton

Antonov-Ovseenko, and Helen Shitikova. 2021. The Print Media Convergence: Overall Trends and the COVID-19 Pandemic Impact. Journal of Risk and Financial Management 14: 364. https://doi.org/10.3390/jrfm 14080364

Academic Editors: Rohail Hassan and Samad M. E. Sepasgozar

Received: 30 May 2021

Accepted: 31 July 2021

Published: 7 August 2021

Publisher's Note: MDPI stays neutral with regard to jurisdictional claims in published maps and institutional affiliations.

Copyright: (c) 2021 by the authors. Licensee MDPI, Basel, Switzerland. This article is an open access article distributed under the terms and conditions of the Creative Commons Attribution (CC BY) license (https:// creativecommons.org/licenses/by/ $4.0 /)$.
1 Department of Economics, Lomonosov Moscow State University, 119991 Moscow, Russia

2 Department of Journalism, Advertising and Public Relations, Tver State University, Zhelyabov Str., 33, 170100 Tver, Russia; education@tversu.ru (L.S.); bryzgalovaelena@gmail.com (E.B.)

3 Department of Publishing and Bibliology, Moscow Polytechnic University, 115280 Moscow, Russia; anton.antonov.ovseenko@gmail.com

4 Publishing Department, Publishing Advertising Alliance Ltd., Tverskaya Str., 20, Bld 3, 125009 Moscow, Russia; helen-shitikova@yandex.ru

* Correspondence: m.sheresheva@gmail.com
Abstract: The study presented in the paper aims to analyze the Russian print media market before and during the COVID-19 pandemic, as well as the prospects of local media transformation in the challenging environment. In the pre-pandemic decade, there was a growing body of literature on media convergence in emerging markets confirming that this concept is growing in importance as a strategic path of conventional media transformation. Still, the research on the Russian conventional media transformation is scarce, the impact of the COVID-19 pandemic risks on Russian print media and their business models have not been investigated so far. To fill the gap, we combined desk research, processing of published industry statistics, and data obtained by means of expert interviews. The results confirm that in the first decades of the 21st century Russian print media paid less attention to the opportunities of media convergence than Western ones. At the same time, those Russian conventional media that set ambitious goals for their future considered the adoption of the media convergence approach as crucial, even before the pandemic. The findings show the lack of systemic measures to improve the overall situation on the national media market that faces difficult times, and the need to take into account pandemic risks in the print media management activities.

Keywords: media convergence; print media; communication; digitalization; SARS-CoV-2; coronavirus; Russia

\section{Introduction}

In 2020-2021, the COVID-19 pandemic influenced all parts of human life. It has had an unprecedented impact on the lifestyle, consumer behavior and quality of life (Laato et al. 2020; Sheth 2020; Berezka et al. 2021; Sheresheva et al. 2021), and on business activity in all sectors of the global economy (Amankwah-Amoah et al. 2020; Bartik et al. 2020; Cavanagh et al. 2020; Donthu and Gustafsson 2020; Polukhina et al. 2021; Sheresheva 2020). The international community "is now in the "acute" stage of reconsidering its problems and risks, capabilities and coordination in the face of COVID-19 and the Global Recession of 2020" (Bobylev and Grigoryev 2020, p. 4).

The current economic situation is highly challenging for print media which faced the need for major changes in the decades before the pandemic, due to digitalization and globalization (Picard 2014). Emergency anti-pandemic measures that resulted in reduced incomes of people, as well as financial problems of investors and advertisers, have come as an unexpected and harsh blow to print media submerged in the process of search for new business decisions and new business models. As a result, they have suffered a substantial volume of additional economic losses in 2020-2021. 
At the same time, pandemics served as a facilitator of media digitalization. Due to restrictions and the need for distancing "multiscreen and digitalization" became "new signs of media consumption, which began to be most clearly traced in 2020" (Zakharova et al. 2021, p. 147). Media industry actors struggling to survive started not only to optimize their operations and look for loans but intensified their search for innovative decisions and models of further development. The management of periodicals has become "the entry point of media convergence" (Chen and Chen 2021, p. 7).

In this regard, the media convergence concept impressively grew in importance and found itself in even higher demand on the current agenda of print media. There is obvious interest to this topic also in emerging markets (Emwinromwankhoe 2020; Fadilla and Sukmono 2021; Lu 2020; Wu 2021). Still, no research has been undertaken on the consequences of COVID-19 pandemic for media convergence in Russia. There is no clear understanding in Russia regarding how national print media react to the new unprecedented challenges and try to cope with them.

The study aims to fill this gap by analyzing the Russian print media market before and during the COVID-19 pandemics, as well as the prospects of local media transformation in the challenging environment. The overall goal is to find better ways to cope with the pandemic crisis and to use the opportunities of the media convergence approach for the revival and success of Russian print media.

The study contributes to the literature on the COVID-19 pandemic impact on the functioning of various industries, as well as to the literature on the media convergence in emerging markets. From our point of view, the potential of media convergence in Russia is not yet fully recognized and still underused, in spite of the growing understanding that there is no alternative to integrate organically the technology of traditional paper media and new media. Additional confirmation of this understanding is that since 2021 the experts of the Association of Russian Communications Agencies (AKAR) started to calculate not only advertising volume spread among distributing media, but also advertising volume by type of content (Table 1). AKAR experts underline the effect of convergence on the business process of mass media in Russia and, in particular, of print media. They rightly comment that in terms of publishing content, advertising revenues from the digital component almost doubled the revenues from the traditional print press: 15.9 billion rubles against 8.0 billion rubles (AKAR 2021a).

Table 1. Content specific advertising in 2020.

\begin{tabular}{lcc}
\hline \multicolumn{1}{c}{ Content Types } & Total Amount, bln Roubles & Change to Previous Year, \% \\
\hline Video content, including: & 190.1 & -3 \\
- traditional TV & 169.0 & -3 \\
- cinema (screen ads) & 0.3 & -75 \\
- $\quad$ online video (stream + VOD) & 20.8 & +5 \\
Audio content, including: & 11.9 & -29 \\
- air broadcast radio & 11.2 & -30 \\
$\quad$ (FM/AM) $\quad$ digital-audio & 0.7 & +3 \\
Publishing content, including & 23.9 & -22 \\
- print $\quad$ digital & 8.0 & -47 \\
- $\quad 15.9$ & +3 \\
Out of Home & 31.9 & -25 \\
Internet services & 215.6 & +4 \\
TOTAL & 473.4 & -4 \\
\hline
\end{tabular}

We analyzed both secondary data sourced from government documents and officially published reports, and the results of expert interviews, to have a broader picture of contemporary market situation and prospects for the near future.

The rest of the paper is organized as follows. Section 2 comprises the literature review on the issues of media convergence, crossmedia and multiplatform concepts that serve 
as the theoretical background of the present research. Section 3 presents the methods implemented in the study and briefly describe the sources of data. In Section 4, we clarify the emerging trend of media convergence on a number of cases from different countries, and then discuss developments on the Russian print media market in the pre-pandemic and pandemic period, as well as the challenges incurred on the market actors by the COVID-19 pandemic. Section 5 contains conclusions, research limitations, recommendations and directions for future research.

\section{Literature Review}

In recent decades, an understanding has emerged that print media need to adapt to new conditions and new readers' demands caused by digitalization. Actually, this is due to the major shift in journalism as a whole at the turn of the century.

In the second half of the 20th century, journalism took shape as a system of professional activities, a set of professions, and a set of scientific disciplines as well. At the beginning of the 21st century, as a result of the development of Internet technologies, journalism has undergone a major transformation due to the urgent need for new principles of work and new requirements for journalists (Aldridge and Evetts 2003; Singer 2003; Le Cam et al. 2019).

Previously, different media types developed as independent and self-sufficient, with their own genre originality and their own peculiarities in the creation and distribution of content. Under the new conditions, in less than one decade, the boundaries between the previously different media types were blurred, completely new forms of the content presentation appeared (Domingo and Heinonen 2008). One witnessed an interpenetration of genres, and some genres have completely disappeared.

Online journalism stepped into the scene as a new generation after conventional journalism and broadcast journalism (Cohen 2002). Some conventional media have fully evolved from newspapers to online media, some continued to work in the traditional format, but could no longer remain within the old paradigm of exclusively print media. "Mature and saturated markets, loss of audiences not highly interested in news, the diminishing effectiveness of the mass media businesses model, the lingering effects of the economic crisis, and the impact of digital competitors" (Picard 2014, p. 488) triggered an intensive search for new approaches that could meet the challenges of the globalized and digitalized world, and this has led to the emergence of the media convergence concept (Arsenijević and Andevski 2015; Baranova 2018).

The initial perception of media convergence has evolved very differently in different countries and regions of the world. The researchers noted that there was no consensus even among experienced expert practitioners (Dwyer 2010; Kim 2019). One should also mention the two related to convergence concepts, namely the crossmedia concept where crossmedia communication refers to "a process whereby two or more media platforms are engaged at the same time in communicating related content" (Erdal 2007, p. 52), and the multiplatform concept where more platforms are engaged in the communication process in an integrated way (Syvertsen and Ytreberg 2006). One more term, namely multi-mediatization, is closely related to the media convergence concept (Baringhorst 2018). The researchers noted that one started talking about multi-mediatization back in the 1980s, though then this term meant not a change in the media content towards multi-media content, but the interweaving of the capitals of various media types" (Kiriya 2010, p. 24).

Since 1997, when the European Commission issued "Green Paper on the convergence of the telecommunications, media and information technology sectors, and the implications for Regulation" back in December 1997 (European Commission 1997), the term "media convergence" has firmly established itself in the lexicon of the mass media market actors. All in all, this term means the merging of formerly discrete communication technologies/media and of their functions and associated genres, facilitated by digitalization (Chandler and Munday 2011). 
The next stage of this process is due to the interpenetration of different media types content based on the growing use of the Internet, the emergence of sites presenting traditional media, and the unification of visual, audiovisual, graphic and text forms of information broadcasting, and the arising online publications as a fundamentally new media type. One could now talk about modern features of convergence and multi-mediatization. As experts noted in the midst of a radical restructuring of traditional media types, the keywords of the modern editorial office and the modern media space were "speed, mobility, multimedia, universality, interactivity" (Kachkaeva 2010).

On the audience side, as Jenkins (2006) underlined, there is a new request for not only search for information but also for taking part in all stages of content production. Moreover, some authors considered that there are two intertwining emergent phenomena: the convergent communications sector and the digital creative economy (Latzer 2013). Domingo and Heinonen (2008) pointed out that the web has brought communications to a completely new path of development, pushing forward a highly diverse communication environment in the true "Castells" sense: a network of communication flows between equally influential nodes capable of acting as senders and recipients of information (Castells 1996) instead of one-way communication flows from several central points to a broad passive audience. In line with this trend, more and more new tools began to appear to enhance the effect of presence, gamification of media content, etc. Even the production of news now involves both representatives of various professions (designers, programmers, etc.) and the audience itself (Novikova and Kiriya 2018).

This, in turn, required significant organizational changes and new management skills. As W. Chen and Y. Chen conclude on the example of sci-tech journals, "periodicals should actively use big data to formulate precise services and "customer first" concepts for providing differentiated services, build a cluster development platform for journals, expand distribution channels by leveraging new technology, connect with the counterpart industry, and set up an online new media communication model" (Chen and Chen 2021, p. 1).

Wikström and Ellonen (2012) investigated how four print media firms have incorporated social media features in their online businesses and how these social media features influence and reshape their online business models. At the core lies the transformation of the firms' value propositions. This transformation has repercussions on the firms' relationship both with its consumers and its traditional content contributors such as journalists and freelance writers. The new value proposition also requires the firms to acquire new competencies in order to be able to reap the full benefit of their social media investments. What is important is that in the cases presented by the researchers the firms have not been able to do so since they have not allowed the social media features to influence their online revenue models (Wikström and Ellonen 2012). These cases unveil the high difficulty of organizational changes implied on print media by the new reality.

Some authors underline the simple fact that before entering the highly competitive field of media convergence, it is necessary to have digital literacy-the ability to find, evaluate, and communicate information on various digital platforms (Lawson-Borders 2006; Prayogi et al. 2020). In this connection, one should admit that the pandemics pushed companies from different industries to digital transformation in their business models (McKinsey 2020; Priyono et al. 2020; Ritter and Pedersen 2020).

We can see that media convergence is understood both as a technological process in journalism and as an applied term, as the fusion of form and the fusion of content. "Technological convergence, media convergence and organizational convergence have helped change the way in which news is made" (Erdal 2007, p. 51).

Thus, we can define convergence as the fusion of different media and technology types (print media, broadcast, TV, photojournalism, etc.) within an online publication. That means that there is underlying consolidation of technologies and services in divisions of one publishing house or telecommunications company. 
In Russia, academics and practitioners also believe that "media convergence is a process in the modern media industry that is directly related to technical advances in information transmission and is based on the principle of crossmedia-one-time production of content and its multiple replications on different media platforms" (Baranova 2010, p. 93) but reasonably emphasize that "converged editorial offices of specific media types are not as autonomous as in conventional holding structures" (Kiriya 2010, p. 24). The very concept of convergence initially perceived in Russia with doubt. "At the beginning of the 21st century, when I first heard the phrase "convergent editorial office", it seemed like another bold invention of Western colleagues, which certainly will not take root on Russian soil soon," said Russian expert Anna Kachkaeva._- "The newspaper people who came from the World Association of Newspapers congresses, could not fully explain the essence of the beginning global changes" (Kachkaeva 2010, p. 6).

Some survey results indicated the move towards the media convergence process in Russia (Baranova 2010). In general, in Russia, not only the widespread acceptance of the media convergence concept but also the full use of the new opportunities that were arising with the emergence of the Internet, took place later than it happened in Europe. For example, while most European print media have added "social media features" to their web-based information services in order to allow users to participate in the production of content (Wikström and Ellonen 2012), many Russian newspapers and magazines, especially on the regional level, were hesitating with such activity.

\section{Materials and Methods}

The overall goal of the study conducted in November 2020-May 2021 was to better understand the impact of COVID-19 on the print media convergence, with additional focus on the Russian market, and thus to elaborate recommendations for print media activity in the new reality taking into account national specifics.

The research questions were as follows:

RQ1. What are the consequences of COVID-19 pandemic for media convergence in Russia?

RQ2. How national print media react on the new unprecedented challenges and try to cope with them?

To obtain the data, we used a combination of desk research, processing of published industry statistics and analysis of qualitative empirical data, collected by means of expert interviews. The expert interviews as a qualitative method allows deviation from the order of questions established in the guide to deeper understand experts' opinions, attitudes and experiences (Legard et al. 2003) were helpful to better access the developments on the Russian print media market. Five expert interviews of approximately $1 \mathrm{~h}$ duration were gathered, transcribed and analyzed. This allowed us to highlight the importance of the media convergence concept for the print media sector in the context of big challenges caused by the COVID-19 crisis.

\section{Results and Discussion}

\subsection{Irreversible Trend of Media Convergence: Similar Cases from Different Countries}

The advantages of internet sources of information (not only online media but also search services, social networks, forums, the blogosphere), in turn, provoked a large-scale and widespread relocation of the attention of information consumers (readers, viewers, and listeners), and therefore advertisers, from traditional mass media types to the global network sources.

The print media have suffered the greatest losses in competition with the Internet. For example, Newsweek, one of the world's most renowned and respected print media companies, became the leader of sad changes in the early 2010s. In mid-October 2012, Newsweek announced its complete phasing out of its paper version from the beginning of 2013 and its transition to digital." New economic realities have left no other options for the journal management. In 2012, Newsweek accumulated \$50 million in debt, the weekly lost 
about $\$ 40$ million a year, and its circulation has more than halved over the past ten years, to 1.5 million copies" (Grabar 2013).

Newsweek was far from the only print media casualty in the US market in the second decade of the XXI century: prior to that, in 2010, the weekly U.S. News \& World Report announced its transition to the Internet. A bit later, the same fate awaited other print editions. In 2016-2020, according to expert evaluations, even the largest newspapers in the United States, such as The Wall Street Journal, USA Today, and The New York Times, have declined in circulation revenue. USA Today led the decline over this four-year period with a negative $45 \%$; the Chicago Tribune achieved a similar figure (-44\%). Just as alarming, albeit smaller, was the decline for the New York Times $(-26 \%)$, and even less for The Wall Street Journal $(-16 \%)$, despite the fact that by 2020 it remained the only newspaper in the United States with a circulation of about 1 million copies. USA Today also had a circulation of about a million copies at the beginning of the four-year recession, but by 2020 it had almost halved to 486,000 copies. For the New York Times, circulation of 410 thousand copies by 2020 turned out to be less than that of USA Today (MediaMedia News 2020)—despite the fact that back in 2018 the number of subscribers to the New York Times print version was about a million copies (GIPP 2019).

As another example, the process of declining circulation in the United States led to the fact that two daily newspapers in Salt Lake City, namely Salt Lake Tribune and Deseret News, announced in October 2020 the transition to a weekly edition by 2021; Deseret News also announced the closure of their printing house. All such reductions immediately led to the personnel dismissal, both creative in editorial offices and production in printing houses (Edmonds 2020).

The downward trend in print media circulation became clearly seen in the early 2010s in Western Europe. In Germany, the daily Frankfurter Rundschau went bankrupt, followed by the Financial Times Deutschland and others; in France, La Tribune refused the printed version, followed by France Soir, etc.

However, the new reality for print media did not look the same everywhere, even in the period of the fiercest competition with internet sources. In the UK, for example, in 2016, sales of printed versions of books and journals, on the contrary, increased by $8 \%$, while sales of electronic versions decreased by $3 \%$. The volume of print sales, according to the British Publishers Association, was then about $£ 3$ billion-the maximum since 2012 (Oskin and Martynov 2017).

In addition, the press development in the Asia-Pacific region countries, especially in China, turned out to be significantly different from how it happened on the American continent and in Western Europe. There, in the early 2010s, the print press held its position in the advertising market with greater success, while the worldwide known US media, such as the aforementioned Newsweek, already started to announce their print versions termination. Despite the fact that in the early 2010s there was a decrease in the share of newspaper advertising in the total media advertising volume, Chinese newspapers outpaced television by more than $15.6 \%$ in terms of advertising revenue growth until June 2011 (Cui 2011).

In China, the print press, in general, remained more resilient by 2020 than the press in most other parts of the world but internet sources took a leading role too, both in the audience attention and in the advertising market (Duan 2020). Along with the losses incurred by the Chinese press in the unequal struggle with the advantages of the Internet, there is also a quite negative impact of the state that concentrated the ownership rights on the main Chinese media, including the Chinese press. As Li (2012) underlined, stateowned media must fulfill the task of ideological propaganda, and newspaper is one of the most important tools for ensuring ideological influence, which is the main obstacle to its development. For example, there are still no publishing companies that could completely dispose of their shares on the stock market. The state form of ownership dominates in the newspaper industry. By 2021, though both the state and private businesses can officially own a newspaper in China, the state-owned newspapers are the leading ones, including 
the Cankao Xiaoxi (Reference News), the Renmin Ribao (People's Daily) and the Global Times that have their own distribution networks abroad. Private or partly state-owned press prevails only in regions.

In the world's largest media market, the United States, the New York Times reported in August 20194.7 million total subscribers (print plus digital); its digital subscription revenue was \$112.6 million, up 14\% year-on-year. And the Guardian reported their second quarter and fiscal year revenues in August 2019, NYT at the time of reporting. In addition, according to investors.nytco.com, NYT earned \$58 million in Q2 from digital product advertising alone. This is $48.1 \%$ of all revenues of the publication for the quarter. NYT earned \$45 million on other products, which is 30\% higher than last year's figures" (NYTCO 2019).

The Guardian's reporting showed that a significant share of its publication revenues are personal receipts from readers: 655 thousand users regularly donate money to support publication, in 2018 they were joined by another 300 thousand one-time donors. As the media editor The Guardian Jim Waterson reported in August 2019 that publication revenues grew by $3 \%$ and amounted to $£ 224$ million over the year. Among all items of income, advertising was $40 \%$, and revenue from readers was $28 \%$. Readers' income grew by $2 \%$ over the year, while advertising fell by $1 \%$. The Guardian received $56 \%$ of its revenues from its digital products and only $43 \%$ from printing, and this figure was steadily declining. (Waterson 2020).

Also, in Israel market demonstrated trends similar to the mentioned above. As General Director of CIS Media Solutions Ilya Bass underlined, in 2019 there were almost two dozen newspapers published in the country, daily and weekly. As a rule, the daily newspapers published in larger volumes and with special supplements on Thursday or Friday. Most of them tended to abandon print publications in favor of electronic ones, and the main players in the electronic media market were traditional media published in a special format. According PwC forecast, in Israel by 2021 digital media revenues from advertising could be almost equal to those of traditional print media, with more than half of the ads displayed on mobile devices.

With the onset of the pandemic, a low mood dominated the European media market. In March 2020, the European press commented on the stock market crash that chilled all markets and reported that the advertising industry "is facing a tsunami, the magnitude of which it is still trying to measure and enumerate the collateral damage to the media" (Debouté 2020). "Globally, the annual investment prospects of advertisers, which usually follow the GDP curve, are mechanically revised downwards," complained Le Figaro. "Analysts predicted that the global market volume will be $\$ 710$ billion this year (of which almost 400 billion in digital form), with an increase of $4 \%$. Now, obviously, there will be much less (a decline of 30 to 50 billion in investments), with a market that will be impacted by a hitherto unknown level in the absence of any data. 2020 was really meant to be a year of glory. However, after the cancellation of major sporting events, including the football Euro, which has been pushed back to 2021, doubts arise about the Tokyo Olympics, and therefore the high market volume (Debouté 2020).

As an example, let us consider the French advertising market. The World Federation of Advertisers (WFA) Treasurer \& CEO Jean-Luc Chetrit lamented that in March 2020 "ad revenues are down $40 \%$ year on year, and the trend will accelerate further to reach $70 \%$ to $80 \%$ of revenue losses in April". Television is far from the only media outlet affected. "We see the same for the press, or radio, where we expect equivalent cuts" (Cassini 2020). Jean-Luc Chetrit was echoed by colleagues from the industry advertising syndicate AACC (l'Association des agences conseil en communication). They stated that more than twothirds of agencies were preparing for the transition to partial unemployment and expected a general decline in advertising activity by $70 \%$.

Long-term and more moderate (in terms of the scale of the recession) forecasts were made by the Union of Consulting Firms and Media purchase in France (Udecam) president Gautier Piquet. Based on a slow recovery of eighteen months scenario and a full return to normal in 2021-2022, G. Piquet stated: "We estimate for 2020, based on up-to-date 
scenarios, a $20 \%$ drop in media investment for television, $13.4 \%$ for radio, $28 \%$ for the press, $5.7 \%$ for digital media, $19.8 \%$ for outdoor advertising and $30 \%$ for the cinema. The overall decline from $12 \%$ to $14 \%$... provided that the state encourages economic recovery through innovative measures such as a tax credit for investments in the communications market" (Richebois 2020).

Thus, the issues of convergence and using multimedia tools have acquired particular importance for all types of media. As François Pellissier, executive president of TF1 advertising division, told Les Echos newspaper, "in TF1, it was customary to say 'content is king'. Today we have to add "media is content with tech and data" because even great content is not enough if we don't integrate the concepts of use that technology and data are revolutionizing" (Le Bolzer 2020). Today media have to integrate different kinds of use, so that any the program is approachable at any time, then distributed in different environments. They must scale their offerings accordingly and measure the overall performance of each content in all possible modes of operation.

For media consumers in the Internet environment, traditional principles of media production have long ceased to exist. There is a fast-growing demand for content targeting, consumption of complex media stories with multi-level and multi-platform representations. As Robert Schumann Foundation experts underlined in 2020, "telecommunications networks, communications services and media play an important role in ensuring economic and social sustainability. They provide the tools needed to virtualize work ... More than ever, the transformative nature of digital innovation in the media and telecommunications industries is affecting the way we live and work" (Pogorel and Preta 2020).

Speaking of convergence, which has undoubtedly accelerated in the media sector, one cannot but talk about the innovations that print publications use in order to survive and achieve success in very difficult conditions summoned by both the general trend for digitalization and the COVID-19 pandemic.

For example, in 2020, the American Washington Post distinguished itself with a whole set of specific innovations, actively and successfully increasing the number of subscribers outside the United States. The WP subscription business has grown by $40 \%$ since the beginning of 2020 compared to 2019 (in this volume, the growth of foreign subscribers accounted for $10 \%$ of the total increase). Mickey King, WP Marketing Director underlined that the regional approach has been a major factor in this success since WP differentiated its policy and subscription prices depending on the region, taking into account its peculiarities. To achieve this, developers are removing barriers to subscribing in other regions, such as currency selection. Partnerships with other publishers also underpin WP's success. WP collaborates with the Financial Times to reciprocally promote subscriptions to boost subscriber growth in the UK. In addition, in 2020, WP introduced The Signal contextual targeting system that helps advertisers to target ads within articles, as well as to select the most appropriate material based on user behavior.

Chinese print media also use innovations to increase traffic and thus to strengthen positions in the market. Experts identify several areas of innovation practiced by Chinese publishers. Firstly, this is the aforementioned cooperation with popular commercial sites. For example, the job advertisements and employment site 51job.com cooperates with 20 newspapers, in particular with the newspaper Nanfang Dushibao. Other innovations are also (51job.com 2021):

- $\quad$ interaction with internet service providers (MSN) or internet instant messaging services (Tencent QQ);

- multifunctional interaction with web portals (for example, Jiefang Ribao has been cooperating with the Sina portal since 2006 in the field of news, mini-blogs, marketing, and capital management);

- creation of own Internet resources in addition to the print edition Internet version, in order to expand the functional significance and increase the audience; for example, People's Daily, back in 2010, created the first news search engine that is still operating (Li 2012). 
As to the COVID-19 pandemic impact on the editorial offices' activity, one should pay attention to the results of a survey by the Reuters Institute. According to the Reuters Institute survey conducted in 2020 in the professional media management environment, $55 \%$ of respondents admitted that a telecommuting practice has become more widespread in the wake of the COVID-19 crisis, and this has made organizations more effective. While $77 \%$ of respondents are concerned that telecommuting can have a negative impact on team creativity, effective communication and employee mental health, it is clear that many news organizations can continue to operate in a more distributed manner even after the crisis. Almost half of the respondents (48\%) said their companies are planning to downsize their physical premises (Cherubini et al. 2020). Hybrid newsrooms-with some employees in the office, some at home, and some on the move (Prastya 2017) - are likely to become an integral part of the future media landscape.

\subsection{The Russian Media Market and COVID-19 Challenges}

By 2021, Russian print media turned out to be in the most difficult situation in the entire post-Soviet period. Retail distribution and subscriptions, as well as advertising revenues, are steadily decreasing, and once-popular weekly and monthly newspapers are disappearing from the market one by one. However, competition with the Internet turns out to be only one of the reasons for their loss of shares in the Russian advertising market.

Firstly, the municipal and regional authorities' activity, aimed at "putting things in order" in the streets of Russian cities, led to the decline in the number of retail outlets (kiosks) selling print media in Russia by more than $50 \%$ in the 2010s. As a result, Russia was among the laggards in this indicator. According to the report of the Russian Union of Printing Industry Enterprises (GIPP) President at the parliamentary hearings in the State Duma (Russian Parliament) in 2019, there are up to 8 outlets selling printing per 10 thousand inhabitants in Europe, and only 2.5 such outlets in Russia (Figure 1). Secondly, a sharp decline in circulation was provoked in 2014 by the abolition of 3.5 billion rubles annual government subsidies for the Russian Post company. These subsidies previously served as compensation for losses on the delivery of subscription printing.

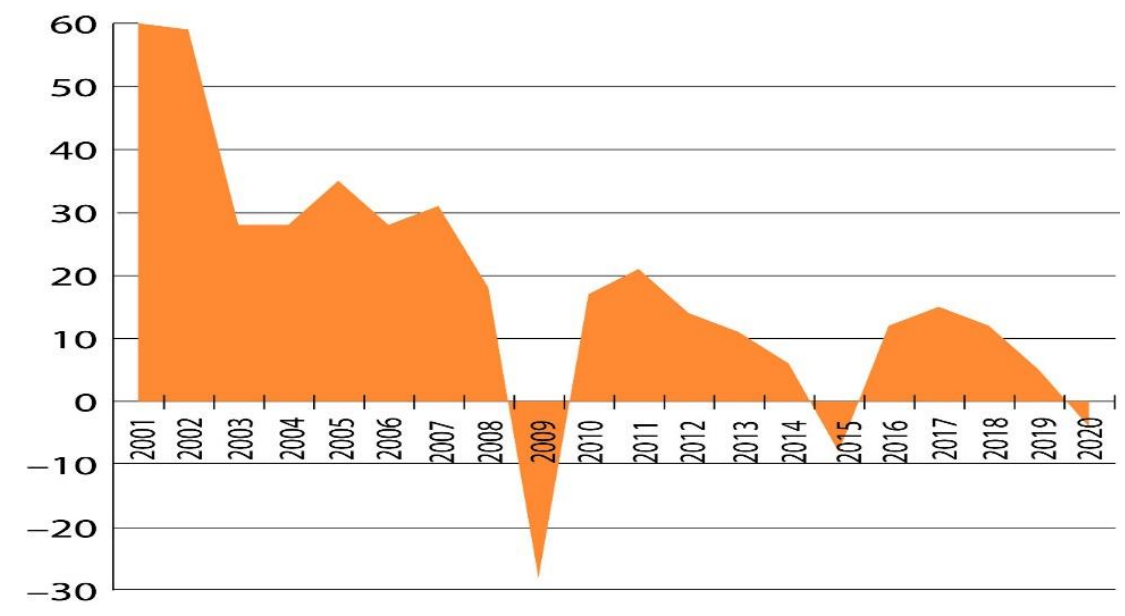

Figure 1. The Russian advertising market dynamics in $2001-2020, \% \%$ for previous period (year) (AKAR 2021b).

There were also additional negative factors, namely:

- the lack of balanced pricing policy for production raw materials (pulp and paper) and materials (offset plates);

- the decrease since 2014 in circulation figures for print media in which a foreign investor can participate in their capital without the government consent. They now need a special agreement to acquire a $25 \%+1$ stake in a print media with a circulation of 
more than 60 thousand copies-whereas earlier this was possible for media with up to 1 million copies;

- the enactment in 2016 of a bill limiting 20\% participation of foreign capital in all Russian media, etc. The gradual decrease in print circulation and thus the reduction in the readership, in turn, led to a reduction in advertising revenue, which in 2019 turned out to be $16 \%$ less than in 2018 .

Development of initiatives to transform the print media business models, taking into account digitalization and shifting in emphasis on networking and content co-creation, was also in place though not yet broadly spread.

Restrictions caused in 2020-2021 by the COVID-19 pandemic made additional negative adjustments to the forecast scenarios and to the overall economy of mass media around the world, especially to the revenue side of print budgets (Figure 2). In Russia, the professional advertisers' community came out with purely pessimistic forecasts regarding the industry's revenues at the end of 2020. According to the survey conducted by the Russian division of the Interactive Advertising Bureau (IAB Russia), in May 2020 44\% of all respondents from 33 firms (members of IAB Russia) noticed that advertisers are postponing or freezing budgets. About $26 \%$ of respondents said they would return previously transferred budgets, and only $22 \%$ were going to continue advertising campaigns in line with the costs planned before the pandemic.

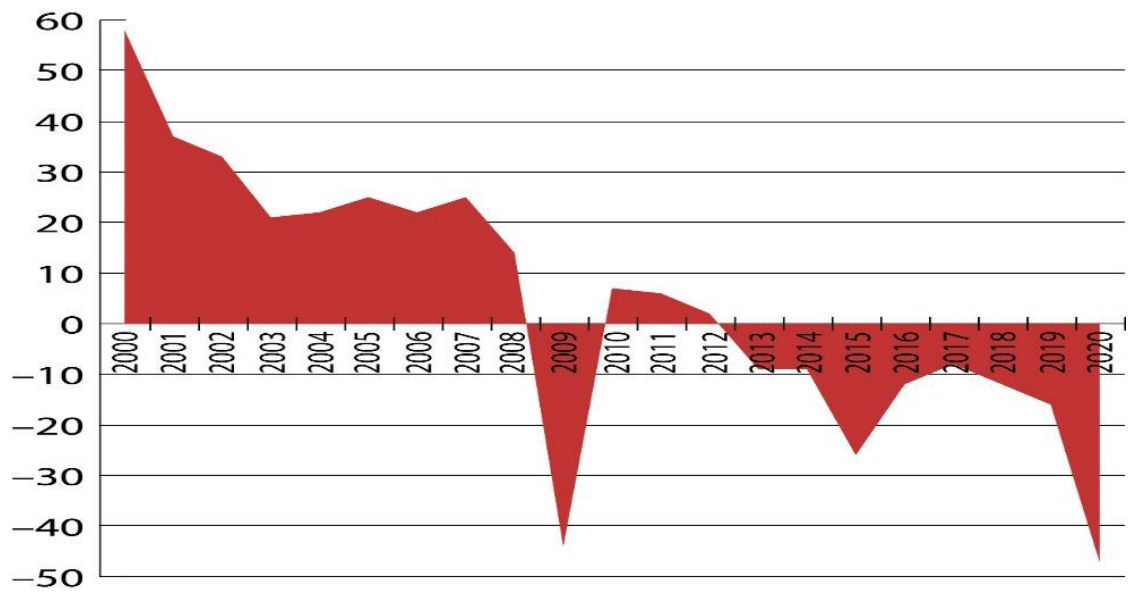

Figure 2. Decline of advertising revenues in Russian print media in 2000-2020, \%\%. Elaborated by the authors based on the "Market Volumes" section on the Association of Russian Communications Agencies portal (AKAR 2021c).

The growth of anxious sentiments had a direct impact on the new contracts' cancellation: $14 \%$ of IAB Russia respondents pointed out this factor, in April already $27 \%$. As for the Russian advertising market prospects, only $4 \%$ of respondents awaited its volume to increase, $8 \%$ said that it will remain the same as in 2019 , but more than $50 \%$ were confident in the forthcoming reduction in the advertising market volume (IAB Russia 2020).

Advertising professionals in Russia were echoed by representatives of related industries and specialized departments. The Russian Union of Journalists (RUJ) chairman Vladimir Soloviev said at a meeting of the State Duma Committee on Information Policy, Information Technology and Communications in May 2020 that 37.5\% of the media polled during the pandemic had a decrease in circulation and number of broadcasts, and almost a third of the editorial offices had to reduce their salaries. According to Soloviev, "by the end of the year, advertising budgets of media will decrease by 30-50\%" (MinComSviaz 2020).

Alexey Volin, the representative of the Ministry of Digital Development, Communications and Mass Media of the Russian Federation (Ministry of Telecom and Mass Communications), made even more gloomy forecasts. He stated that the fall in the advertising income of domestic media due to the pandemic will amount to $30 \%$ by the end of 2020 . 
In monetary terms, the industry losses could reach 100 billion rubles; TV is threatened with losses on the advertising revenues reduction of about 50 billion rubles, radio-about 8 billion rubles. As for newspapers, the probable losses counted for about 11 billion rubles (cumulatively for print and electronic versions), as well as about 10 billion rubles due to downturn in retail sales and subscriptions (MinComSviaz 2020).

At the same time, as it turned out later, a completely different situation developed in the Russian Internet advertising market. Thus, the Russian division of PwC reported in its regular review of the media and entertainment industry that there was a recovery in budgets in this sector in the second half of 2020 in Russia. After the cancellation of the self-isolation regime, there was an increase in demand in the FMCG and retail segments, and the offline points of sale opening had a positive effect on the market as a whole. Taking into account all the factors, PwC assessed a 5\% growth in the Russian online advertising market by the end of 2020 and forecasted that it will reach $\$ 5.3$ billion by 2024, with an average annual growth rate of $7.4 \%$.

These bold forecasts by PwC based on data on the massive growth of Internet users in Russia: "Over the past 5 years, the number of Internet users in Russia has increased significantly. During this period, the number of broadband Internet connections increased by 5 million households and reached 33.3 million households, which is $65.1 \%$ of all households in Russia. The number of mobile Internet subscribers has grown even more-from 81.3 million to 106.2 million" (Media Outlook 2020). In its forecasts, PwC apparently also proceeded from the simple calculation that the steadily increasing volumes of the online advertising market before the pandemic (including due to the "overflow" of funds from traditional types of media) should increase even more during the period of anti-pandemic restrictions.

The Russian professional media and advertising community, taking into account the prevailing negative background with advertising revenues, counted on the state support but these expectations were only partially met. In 2020, Russian Prime Minister Mikhail Mishustin signed a decree on the inclusion of media and print production activities in the list of sectors affected by the COVID-19 pandemic. Publishers of books, newspapers, magazines, TV companies and radio stations, online media and news agencies were able to get relevant state support. The list also included activities related to the printing of newspapers (printing companies) (GIPP 2020). At the same time, not all mass media could receive state support for bureaucratic reasons. Some media included in their constituent documents such a number of the All-Russian Classifier of Economic Activities (OKVED), which did not correspond (or did not correspond directly) to the media types-while the officials in the distribution of state support proceeded from the direct correspondence of the first (main) OKVED number to the media production. Actually, Russian mass media, primarily the press tried to survive in the difficult conditions of the economic sanctions imposed on Russia from 2014 by changing the classifier, while not stopping the main activity. However, due to the tough position of Russian officials, this became a strict barrier to receive state support.

As a result of intensive anti-coronavirus measures, Russia has successfully "flattened the curve" on the COVID-19 pandemic in Spring-Summer 2020 and began the vaccination process. At the time of writing, on 30 May 2021, Russia has had more than million $(5,063,442)$ confirmed cases, 121,162 deaths and 4,677,870 recoveries (Stop Coronavirus 2021). There was only one two-month lockdown in March-April 2020 and no more lockdowns up to now. Nevertheless, some restrictions introduced to control the pandemic are still in place, and discussion has now moved to how business can return to a new normal after sharp decline in all segments of the Russian market.

In 2020, due to the COVID-19 pandemic, the revenues from advertising on the Russian media market declined, like in the world market as a whole. Oil prices shock added to the pandemic consequences, and a sharp rise in the exchange rate against the ruble aggravated the situation in the Russian advertising industry. 
As shown in Figure 1, the Russian advertising market volume gradually decreased from 2001 to 2020. Concerning such advertising channels as mass media, excluding the Out of Home sector and marketing services, this process is similar to the rest of the world. It is accompanied by the income relocation from traditional media types to the Internet, and in online media to the least extent: the lion's share of advertising revenue is taken by search services and social networks. At the same time, as noted by Sergey Veselov, vice-president of the Association of Russian Communications Agencies (AKAR), "the Russian advertising market went through a difficult 'COVID year' much better than the overwhelming majority of foreign advertising markets: while the global advertising market fell by $7.5 \%$, the Russian market shrank by only $4 \%$. At the same time, Western Europe markets lost on average about $12 \%$ of advertising budgets, India, Brazil, and Mexico up to $10-17 \%$, Japan-8\%, etc." (GIPP 2020).

A significant part of the large Russian publishing houses' advertising budgets by 2020 were steadily replenished not in the sub-segment of printed products, but on their websites in the global network. According to the Association of Russian Communications Agencies, for some publishing houses, this figure reached 70\% already in 2019. This helped them to survive in the pandemic crisis.

\subsection{Discussion}

The downward trend in print media circulation was not the result of the COVID-19 pandemics crisis. This trend emerged at the beginning of the 21st century pushed by the relocation of information consumers' attention to the internet sources of information. The need to adjust the print media strategies to the new circumstances was noted by academics and practitioners all over the world, though the pace and manifestation of this adjustment were not the same in different countries.

With the onset of the pandemic, the industry faced unprecedented challenges that triggered the changes in the world media industry, shift to multimedia tools among them. Therefore, the issues of convergence became crucial for all types of media.

Based on the results of the study, we can state that before the COVID-19 pandemics the large Russian publishing houses were quite active in the transition to the principles of media convergence, while the smaller print media were hesitant to use the benefits of this approach. In times of the COVID-19 crisis, the use of the Internet became much more intensive, and more sustainable appeared to be those media that managed to switch to a multi-platform approach and active interaction with the audience for the joint creation of content.

Therefore, to gain success, including in terms of development funds economy, any produced content has to be reproduced many times on different platforms. The restructuring of editorial offices in favor of "media conductors", "news desks", and editors of multimedia products seem to be no less important. In this case, the vertical subordination changes to a more flexible horizontal information exchange, and most employees' functionality changes from specialized to universal.

This principle of building the modern editing business structure actually corresponds to the matrix organization principle. There is literature confirming the advantages of matrix structure, both in the course of the implementation projects limited in space and time, and in the working out of permanent production process. At the same time, the main advantages of matrix structure, flexibility and efficiency can become its actual backsides (Goś 2015). So, matrix organization can be a good principle for mass media, but it should only be used if there is a strong purpose and that purpose can penetrate the whole organization. "A matrix can only be successful if a number of important contingencies-climate, leadership, knowledge sharing, information technology, incentives, etc.- are correctly designed and aligned with one another" (Burton et al. 2015, p. 43). For such a structure, recruitment of employees with a high qualifications level and talent management are crucial.

It is important to take into account that the COVID-19 pandemics has accelerated not only the processes of convergence in journalism and the media business as a whole, 
but also contributed to the impressive strengthening of social networks role. Social media usage becomes and important communication feature among citizens as well as for both public and private sectors (Chen et al. 2020; Demircioglu 2018; Fuchs 2017; Oksa et al. 2021), future studies may also analyze how COVID-19 pandemic has affected use of social media among citizens, consumers and employees. Many newspapers and magazines all over the world have added "social media features" to their web-based information services in order to allow users to participate in the production of content, and this led to online business model innovation, particularly linked to the firms' value propositions (Wikström and Ellonen 2012). Russian print media should be more active in investing in social media features and in other possible opportunities of content co-creation on their business models.

\section{Conclusions}

Based on the results of the conducted study, we can make some concluding remarks.

The current economic situation is highly challenging for print media all over the world. In the last decades, print media faced the need for major changes due to digitalization and globalization. Therefore, many of them appeared to be in the process of transformation when COVID-19 pandemics forced the international community to reconsider its problems and risks in the face of unprecedented lockdowns. In this context, the search for new business decisions and new business models became crucial for many media market actors. The media convergence concept that was on the agenda of conventional media since the end of the 20th century attracted even more attention than before.

Print media around the world, both those suffering losses in the fight against the consequences of the pandemic and in competition with the Internet, and those suffering from administrative interference (or inaction), react to what is happening in the only possible way. They develop multimedia, i.e., use convergent journalism tools that create conditions to increase the audience by attracting internet users. In turn, the growth of the real aggregate audience provides media with adequate interest from advertisers.

Both media and advertising academics and practitioners agree that nowadays the crossmedia principle plays a primary role in the transformation of any editorial office.

In this paper, we focused on the media convergence concept in relation to Russian print media. The findings show the lack of systemic measures to improve the overall situation on the national media market that faces difficult times.

The study contributes to the academic literature on the COVID-19 pandemics risks impact on the functioning of various industries, as well as to the literature on the media convergence in emerging markets by exploring newest developments in the crisis period.

Our results provide valuable insights for organizations to consider in their daily work practices, namely the need to take into account pandemic risks in the print media management activities. All of the above invariably leads to optimization and reduction cost of collection, delivery, processing and publication of materials. Therefore, there is no alternative to switching to $24 / 7$ broadcasting and to restructuring the editorial space in favor of heliocentrically located newsrooms, etc.

Adaptive business development that uses the convergence approach opens up opportunities for new media platforms as new sources of income for print media companies and new opportunities for attracting advertisers. Media services are highly audience-oriented and therefore consumers are the focus of business activity.

Thus, it is crucial for market actors to adjust to the great shift in consumer behavior induced by the information technologies development, especially to the increased interest in content co-creation. Under these conditions, permanently considering of the audience interest also becomes a factor of success for mass media and is in the list of our recommendations.

Thus, the goal of any contemporary mass media is not the attempt to preserve its traditional form of release (which is deliberately fruitless), but the main brand development based on multimedia: the media release platform is less important than the "banner" of 
this media. We propose this approach as a top recommendation for mass media, including Russian print media.

There are a number of limitations to this study. At present, our results based on secondary data and qualitative empirical data give us a number of valuable insights concerning the shift in the print media market, but the lack of empirical data obtained on a broader representative sample is the biggest limitation. Therefore, as a promising avenue for future research, we consider the collection of micro-economic data from a sample of Russian print media, with the aim to unveil long-term changes in this sector.

As social media usage becomes an important communication feature among citizens as well as for both public and private sectors, future studies may also analyze how COVID19 pandemic has affected use of social media among citizens, consumers and employees. Our future research will also focus on the exploration of user resources and on the issues of gaining real profits from the transition to converged journalism.

Author Contributions: Conceptualization, M.S., L.S. and E.B.; methodology, M.S. and A.A.-O.; validation, H.S.; formal analysis, A.A.-O.; resources, L.S., E.B. and A.A.-O.; data curation, A.A.-O.; writing—original draft preparation, M.S. and A.A.-O.; writing—review and editing, M.S.; supervision, M.S. All authors have read and agreed to the published version of the manuscript.

Funding: This research received no external funding.

Data Availability Statement: The data presented in this study are partly available on https:/ /www. akarussia.ru (accessed on 5 July 2021) and https: / / rosstat.gov.ru (accessed on 5 July 2021). Transcrips of expert interviews are available on request from the corresponding author.

Conflicts of Interest: The authors declare no conflict of interest.

\section{References}

51job.com. 2021. Available online: https:/ / www.51job.com (accessed on 5 July 2021).

Association of Russian Communications Agencies (AKAR). 2021a. Advertising in the Context of Content Type in 2020. Available online: https: / / www.akarussia.ru/knowledge/market_size/id9586 (accessed on 25 June 2021).

Association of Russian Communications Agencies (AKAR). 2021b. The Russian Advertising Market Dynamics in 2001-2020. Available online: https://www.akarussia.ru/vol_2 (accessed on 23 April 2021).

Association of Russian Communications Agencies (AKAR). 2021c. The Russian Advertising Market Structure in 2001-2020. Available online: https:/ / www.akarussia.ru/vol_3 (accessed on 25 April 2021).

Aldridge, Meryl, and Julia Evetts. 2003. Rethinking the concept of professionalism: The case of journalism. The British Journal of Sociology 54: 547-64. [CrossRef]

Amankwah-Amoah, Joseph, Zaheer Khan, and Geoffrey Wood. 2020. COVID-19 and business failures: The paradoxes of experience, scale, and scope for theory and practice. European Management Journal 39: 179-84. [CrossRef]

Arsenijević, Jasmina, and Milica Andevski. 2015. Media Convergence and Diversification-The Meeting of Old and New Media. Procedia Technology 19: 1149-55. [CrossRef]

Baranova, Ekaterina. 2010. Media Convergence through the Eyes of Russian Practicing Journalists. Vestnik Moskovskogo Universiteta. Seriya 10. Zhurnalistika, pp. 93-100. Available online: https://vestnik.journ.msu.ru/books/2010/4/konvergentsiya-smiglazami-rossiyskikh-zhurnalistov-praktikov / (accessed on 19 May 2021).

Baranova, Ekaterina. 2018. Media Convergence as a System-Forming Factor of Transformation of the Media Institute. Moscow: Universe Books.

Baringhorst, Sigrid. 2018. Introduction: Political campaigning in changing media cultures-Typological and historical approaches. In Political Campaigning on the Web. Bielefeld: Transcript-Verlag, pp. 9-30.

Bartik, Alexander W., Marianne Bertrand, Zoë B. Cullen, Edward L. Glaeser, Michael Luca, and Christopher T. Stanton. 2020. The impact of COVID-19 on small business outcomes and expectations. Proceedings of the National Academy of Sciences 117: 17656-66. [CrossRef]

Berezka, Svetlana, Vera Rebiazina, and Snezhana Muravskaia. 2021. Changes in consumer behavior in the BRICS countries during the COVID-19 pandemic: The role of trust and anxiety. BRICS Journal of Economics 2: 53-73. [CrossRef]

Bobylev, Sergey, and Leonid Grigoryev. 2020. In search of the contours of the post-COVID Sustainable Development Goals: The case of BRICS. BRICS Journal of Economics 2: 4-24. [CrossRef]

Burton, Rich, Borge Obel, and Dorthe Haakonsson. 2015. How to get the matrix organization to work. Journal of Organization Design 4: 37-45. [CrossRef] 
Cassini, Sandrine. 2020. Sous l'effet de la pandémie due au coronavirus, le marché publicitaire fléchit sévèrement. Le Monde, March 25. Available online: https://www.lemonde.fr/economie/article/2020/03/25/sous-1-effet-de-la-pandemie-due-au-coronavirusle-marche-publicitaire-flechit-severement_6034365_3234.html(accessed on 19 April 2021).

Castells, Manuel. 1996. The Rise of the Network Society. Malden: Blackwell Publishers.

Cavanagh, David, Mark Hoey, Andrew Clark, Michael Small, Paul Bailey, and Jon Watson. 2020. West Australian Pandemic Response: The Black Swan of Black Swans. Available online: https:/ /arxiv.org/pdf/2008.08918.pdf (accessed on 19 September 2020).

Chandler, Daniel, and Rod Munday. 2011. A Dictionary of Media and Communication, 2nd ed. Oxford: OUP Oxford.

Chen, Wenlan, and Yuan Chen. 2021. Research on the Promotion Path of Marketing Strategy of Sci Tech Journals from the Perspective of Media Convergence. Open Access Library Journal 8: 1-9. [CrossRef]

Chen, Qiang, Junyan Hu, Wei Zhang, Richard Evans, and Xiaoyue Ma. 2020. Employee use of public social media: Theories, constructs and conceptual frameworks. Behaviour E Information Technology, 1-25. [CrossRef]

Cherubini, Federica, Nic Newman, and Rasmus Kleis Nielsen. 2020. Changing Newsrooms 2020: Addressing Diversity and Nurturing Talent at a Time of Unprecedented Change. Oxford: Reuters Institute, October 29, Available online: https://reutersinstitute.politics ox.ac.uk/changing-newsrooms-2020-addressing-diversity-and-nurturing-talent-time-unprecedented-change (accessed on 19 December 2020).

Cohen, Elisia L. 2002. Online journalism as market-driven journalism. Journal of Broadcasting E Electronic Media 46: $532-48$.

Cui, Baoguo, ed. 2011. Blue Book of China's Media: Report on Development of China's Media Industry. Beijing: Social Sciences Academic Press (China).

Debouté, Alexandre. 2020. Coronavirus: L'activité publicitaire durement touché. Le Figaro, March 23. Available online: https: //www.lefigaro.fr/medias/coronavirus-1-activite-publicitaire-durement-touchee-20200323(accessed on 19 April 2021).

Demircioglu, Mehmet Akif. 2018. Examining the Effects of Social Media Use on Job Satisfaction in the Australian Public Service: Testing Self-Determination Theory. Public Performance E Management Review 41: 300-27.

Domingo, David, and Ari Heinonen. 2008. Weblogs and journalism: A typology to explore the blurring boundaries. Nordicom Review 29: 3-15. [CrossRef]

Donthu, Naveen, and Anders Gustafsson. 2020. Effects of COVID-19 on business and research. Journal of Business Research 117: 284-89. [CrossRef] [PubMed]

Duan, Peng. 2020. Media Convergence and the Development Strategies of Radio and Television in China. London: Springer Nature.

Dwyer, Tim. 2010. Media Convergence. Maidenhead: McGraw-Hill Education.

Edmonds, Rick. 2020. Seven-day newspaper print editions will disappear in Salt Lake City early next year. Poynter, October 27. Available online: https:/ / www.poynter.org/locally/2020/seven-day-newspaper-print-editions-will-disappear-in-salt-lakecity-early-next-year/(accessed on 22 May 2021).

Emwinromwankhoe, Osakpolor. 2020. Media Convergence and Broadcasting Practice in Nigeria: Three Broadcast Stations in Focus. Covenant Journal of Communication 7: 26-52. Available online: http://journals.covenantuniversity.edu.ng/index.php/cjoc/article/ view/2125/1150 (accessed on 20 May 2021).

Erdal, Ivar John. 2007. Researching media convergence and crossmedia news production: Mapping the field. Nordicom Review 28: 51-61. [CrossRef]

European Commission. 1997. Green Paper on the Convergence of the Telecommunications, Media and Information Technology Sectors, and the Implications for Regulation. Brussels: European Commission, December 3, Available online: https: / / ec.europa.eu/archives / information_society/avpolicy/docs/library/legal/com/greenp_97_623_en.pdf (accessed on 10 May 2021).

Fadilla, Qholiva Yuni, and Filosa Gita Sukmono. 2021. Transformation of print media in the digital era: Media convergence of Kedaulatan Rakyat. International Journal of Communication and Society 3: 27-38.

Fuchs, Christian. 2017. Social Media: A Critical Introduction. London: Sage.

Russian Union of Printing Industry Enterprises (GIPP). 2019. NYT and Guardian Reported Income. Available online: https: / / gipp.ru/ news/zarubezhnye-smi/nyt-i-guardian-otchitalis-o-dokhodakh/ (accessed on 12 January 2021).

Russian Union of Printing Industry Enterprises (GIPP). 2020. The Russian Union of Journalists Will Ask to Clarify the Mechanism for Obtaining State Support for the Media. Available online: https://gipp.ru/news/novosti-otrasli/szhr-poprosit-utochnitmekhanizm-polucheniya-gospodderzhki-smi/ (accessed on 12 January 2021).

Goś, Krzysztof. 2015. The key advantages and disadvantages of matrix organizational structures. Studia i Materiały 2: 66-83. [CrossRef]

Grabar, Yakov. 2013. The Future of Print Media: Circulation Is Falling, Online Editions Are Growing. Available online: https: //www.rbc.ru/economics/13/02/2013/570403709a7947fcbd445a46 (accessed on 20 May 2021).

IAB Russia. 2020. The COVID-19 Impact on Adevrtising Market. Available online: https:/ / iabrus.ru/projects/1849 (accessed on 12 January 2021).

Jenkins, Henry. 2006. Convergence Culture: Where Old and New Media Collide. New York: New York University Press.

Kachkaeva, Anna. 2010. From the editor. Catching up with the future. In Journalism and Convergence: Why and How Traditional Media Are Turning into Multimedia. Moscow: Aspect Press. (In Russian)

Kim, Hyung Whan. 2019. Media Convergence: Concept, Discourse and Influence. London: University of London.

Kiriya, Ilya. 2010. What is multimedia? In Journalism and Convergence: Why and How Traditional Media Are Turning into Multimedia. Moscow: Aspect Press. (In Russian) 
Laato, Samuli, Najmul Islam, Ali Farooq, and Amandeep Dhir. 2020. Unusual purchasing behavior during the early stages of the COVID-19 pandemic: The stimulus-organism-response approach. Journal of Retailing and Consumer Services 57: 102224. [CrossRef]

Latzer, Michael. 2013. Media Convergence. In Handbook on the Digital Creative Economy. Cheltenham and Northampton: Edward Elgar Publishing.

Lawson-Borders, Gracie L. 2006. Media Organizations and Convergence: Case Studies of Media Convergence Pioneers. London: Routledge.

Le Bolzer, Julie. 2020. CES de Las Vegas: Pourquoi Gilles Pélisson s'y rend chaque année. Les Echos, January 7. Available online: https: / www.lesechos.fr/idees-debats /leadership-management/ces-de-las-vegas-pourquoi-gilles-pelisson-sy-rendchaque-annee-1244681(accessed on 20 May 2021).

Le Cam, Florence, Fábio Henrique Pereira, and Denis Ruellan. 2019. Professional Identity of Journalists. The International Encyclopedia of Journalism Studies: 1-7. [CrossRef]

Legard, Robin, Keegan Jill, and Kit Ward. 2003. In-depth interviews. Qualitative Research Practice: A Guide for Social Science Students and Researchers 6: 138-69.

Li, Xuan. 2012. The Impact of New Media on the Chinese Press. MediaAlmanach 3: 55-62. (In Russian).

Lu, Xinyu. 2020. Lessons from Weibo: Media Convergence and Contemporary Chinese Politics. Javnost-The Public 27: 126-39. [CrossRef]

McKinsey. 2020. COVID-19: Implications for Business. Available online: https:/ / www.mckinsey.com/business-functions/risk/ourinsights / covid-19-implications-for-business\# (accessed on 21 May 2021).

Media Outlook. 2020. Media Industry in 2020-2024 Annual Review of the Global and Russian Entertainment and Media Industries. Available online: https:/ / www.pwc.ru/ru/publications/media-outlook-2020/media-outlook-2020-2024.pdf (accessed on 29 May 2021).

MediaMedia News. 2020. Major US Newspapers Have Lost 30\% of Circulation Revenue Since 2016. October 22. Available online: http:/ / mediamedia.me/news/ (accessed on 19 May 2021).

Ministry of Digital Development, Communications and Mass Media of the Russian Federation (MinComSviaz). 2020. Advertising revenues of mass media by the end of the year may fall by 30\%. Kommersant, May 12. Available online: https://www.kommersant. $\mathrm{ru} / \mathrm{doc} / 4342372$ (accessed on 10 November 2020).

Novikova, Anna, and Ilya Kiriya. 2018. Aesthetics of immersion: Creativity of the journalist in multimedia and transmedia projects. Vestnik of Saint Petersburg University. Language and Literature 15: 276-88. [CrossRef]

NYTCO. 2019. Investor Relations. Available online: https://www.nytco.com/investors/investor-relations/ (accessed on 15 September 2019).

Oksa, Reetta, Tiina Saari, Markus Kaakinen, and Atte Oksanen. 2021. The Motivations for and Well-Being Implications of Social Media Use at Work among Millennials and Members of Former Generations. International Journal of Environmental Research and Public Health 18: 803. [CrossRef] [PubMed]

Oskin, Aleksander, and Dmitry Martynov. 2017. What is happening with the publishing business all over the world. Journalist, June 26. Available online: https://jrnlst.ru/izdatelskie-tendencii-v-mire-perelom-nastupaet(accessed on 21 May 2021).

Picard, Robert G. 2014. Twilight or new dawn of journalism? Evidence from the changing news ecosystem. Journalism Practice 8: 488-98. [CrossRef]

Pogorel, Gérard, and Augusto Preta. 2020. La convergence «médias et télécoms» à l'épreuve de la COVID-19. Fondation de Robert Chuman. Question d’Europe N559. Available online: https: / / www.robert-schuman.eu/fr/doc/questions-d-europe/qe-559-fr. pdf (accessed on 25 May 2021).

Polukhina, Anna, Marina Sheresheva, Marina Efremova, Oxana Suranova, Oksana Agalakova, and Anton Antonov-Ovseenko. 2021. The concept of sustainable rural tourism development in the face of COVID-19 crisis: Evidence from Russia. Journal of Risk Financial Management 14: 38. [CrossRef]

Prastya, Narayana Mahendra. 2017. Media convergence and human resoucres management in sport media newsroom: Case study in TopSkor Daily Newspaper. Jurnal Komunikasi Ikatan Sarjana Komunikasi Indonesia 2: 57-64. [CrossRef]

Prayogi, Ichsan A., Nuryah A. Sjafirah, and Evie A. S. Dewi. 2020. Media Convergence Welcomes Industry 4.0. Jurnal Komunikasi Ikatan Sarjana Komunikasi Indonesia 5: 199-204. [CrossRef]

Priyono, Anjar, Abdul Moin, and Vera Nur Aini Oktaviani Putri. 2020. Identifying Digital Transformation Paths in the Business Model of SMEs during the COVID-19 Pandemic. Journal of Open Innovation: Technology, Market, and Complexity 6: 104. [CrossRef]

Richebois, Véronique. 2020. Les groupes de communication calculent le coût sévère de «l'après». Les Echos, April 28. Available online: https:/ / mcusercontent.com/67dce269d46cd6e1d19491199/files/a9caf4d9-b628-4f75-8e72-ab8d430146bd/Les_Echos_ 28042020_Groupes_de_communication.pdf(accessed on 12 December 2020).

Ritter, Thomas, and Carsten Lund Pedersen. 2020. Analyzing the impact of the coronavirus crisis on business models. Industrial Marketing Management 88: 214-24. [CrossRef]

Sheresheva, Marina Y. 2020. Coronavirus and tourism. Population and Economics 2: 72-76. [CrossRef]

Sheresheva, Marina, Marina Efremova, Lilia Valitova, Anna Poilukhina, and Georgy Laptev. 2021. Russian Tourism Enterprises' Marketing Innovations to Meet the COVID-19 Challenges. Sustainability 13: 3756. [CrossRef]

Sheth, Jagdish. 2020. Impact of COVID-19 on consumer behaviour: Will the old habits return or die? Journal of Business Research 117: 280-83. [CrossRef] 
Singer, Jane B. 2003. Who are these guys? The online challenge to the notion of journalistic professionalism. Journalism 4: 139-63. [CrossRef]

Stop Coronavirus. 2021. Official Information of the Russian Government on Coronavirus in Russia. Available online: https: / / xn--80aesfpebagmfblc0a.xn--p1ai/ (accessed on 30 May 2021).

Syvertsen, Trine, and Espen Ytreberg. 2006. Current Research Projects. Participation and Play in Converging Media: Institutional Perspectives and Text-user Relations. Nordicom Review 27: 107-10. [CrossRef]

Waterson, Jim. 2020. Guardian Broke Even Last Year, Parent Company Confirms. Available online: https://www.theguardian.com/ media/2019/aug/07/guardian-broke-even-last-year-parent-company-confirms (accessed on 18 May 2021).

Wikström, Patrik, and Hanna-Kaisa Ellonen. 2012. The impact of social media features on print media firms' online business models. Journal of Media Business Studies 9: 63-80. [CrossRef]

$\mathrm{Wu}$, Shuxi. 2021. Television Adaptation in the Age of Media Convergence: Chinese Intellectual Property Shows and the Case of All Is Well. Adaptation. [CrossRef]

Zakharova, Aleksandra V., Elena Yu Karmalova, and Alexey D. Krivonosov. 2021. Media Preferences of Schoolchildren During the COVID-2019 Pandemic and the Impact of Digitalization on their Media Consumption. Paper presented at 2021 Communication Strategies in Digital Society Seminar (ComSDS), St. Petersburg, Russia, April 14. 